\title{
Cover crops reduce water drainage in temperate climates: A meta-analysis
}

\author{
Nicolas Meyer ${ }^{1}$ (D) Jacques-Eric Bergez ${ }^{1} \cdot$ Julie Constantin $^{1} \cdot$ Eric Justes $^{1,2}$
}

Accepted: 12 November 2018 / Published online: 17 December 2018

(C) INRA and Springer-Verlag France SAS, part of Springer Nature 2018

\begin{abstract}
Cover crops provide many ecosystem services, such as soil protection, nitrate pollution of water mitigation, and green manure effects. However, the impact of cover crops on soil water balance is poorly studied, despite its potential impact on groundwater recharge. Some studies reported a reduction of the water drainage due to an increase of the evapotranspiration by plant cover transpiration. However, there is no real consensus on the intensity of this phenomenon, which highlights the importance to quantify the impact of cover crops on drainage compared to that of bare soil. We performed a meta-analysis of published papers presenting studies on the impact of cover crops on drainage compared to that of bare soil under temperate climates. Of the 436 papers identified, 28 of them were included in the analysis based on criteria required for performing a relevant meta-analysis. The originality of our study lies in two following results: (1) the quantification of drainage reduction with cover crops by a mean effect size of $27 \mathrm{~mm}$ compared to that of bare soil and (2) within the large variability of soils, climates, and cropping systems, no main determining factor was found significant to explain the variability of water drainage reduction. The cover crops provide a service of nitrate pollution mitigation, but the drainage reduction could be considered as a disservice, because they can lead to a reduction in groundwater recharge due to a higher evapotranspiration in comparison to bare soil. This highlights the need of research for optimizing trade-offs between services and disservices of cover crops for water balance.
\end{abstract}

Keywords Catch crops $\cdot$ Review $\cdot$ Groundwater recharge $\cdot$ Water balance $\cdot$ Pedoclimatic factors $\cdot$ Biomass

\section{Introduction}

Cover crops are sown during the fallow period between two main cash crops and are grown for 2-8 months, depending on the crop rotation (Fig. 1). When they are destroyed, their biomass is returned to the soil, being either incorporated or left at the soil surface as a mulch. Cover crops are a useful agroecological tool that can provide multiple ecosystem services. Cover crops protect and improve soil physical properties, such as reducing soil erosion (Ryder and Fares 2008), and provide several biological ecosystem services, such as controlling pests, diseases, and weeds, and improving biodiversity (Haramoto

Nicolas Meyer

nicolas.meyer@inra.fr

AGIR, Université de Toulouse, INRA, Castanet-Tolosan, France

2 CIRAD, UMR SYSTEM Univ. Montpellier, CIHEAM-IAMM, CIRAD, INRA, Montpellier SupAgro, Montpellier, France and Gallandt 2005; Schipanski et al. 2014). When well-managed, they also reduce nitrate leaching and increase the green manure effect, which increases soil nitrogen content in cropping systems (Tosti et al. 2014; Tribouillois et al. 2015). Cover crops also increase the carbon content of soils (Poeplau and Don 2015; Tribouillois et al. 2018), which helps to mitigate effects of climate change, as highlighted in the international " 4 per 1000" initiative (Demenois 2017). While government policies and climate change may therefore increase the use of cover crops, the IPCC reports that the future will have more droughts and greater variability in rainfall (IPCC 2013), which will increase water management challenges.

The impact of cover crops on water balance is not widely documented in the literature, and its net effect on annual drainage, i.e., water transfer to groundwater below the soil zone explored by crop roots, is debated. Cover crops reduce soil evaporation and increase plant cover transpiration, increasing evapotranspiration compared to that of bare soil (Qi et al. 2011a; Nielsen et al. 2015a). Cover crops also increase water infiltration and reduce runoff (Eshel et al. 2015; Yu et al. 2016). Although studies agree on these effects, the magnitude 
Fig. 1 Comparison of cover crop treatment to that of bare soil. At the top, sorghum, and at the bottom, white mustard, 6 weeks after sowing

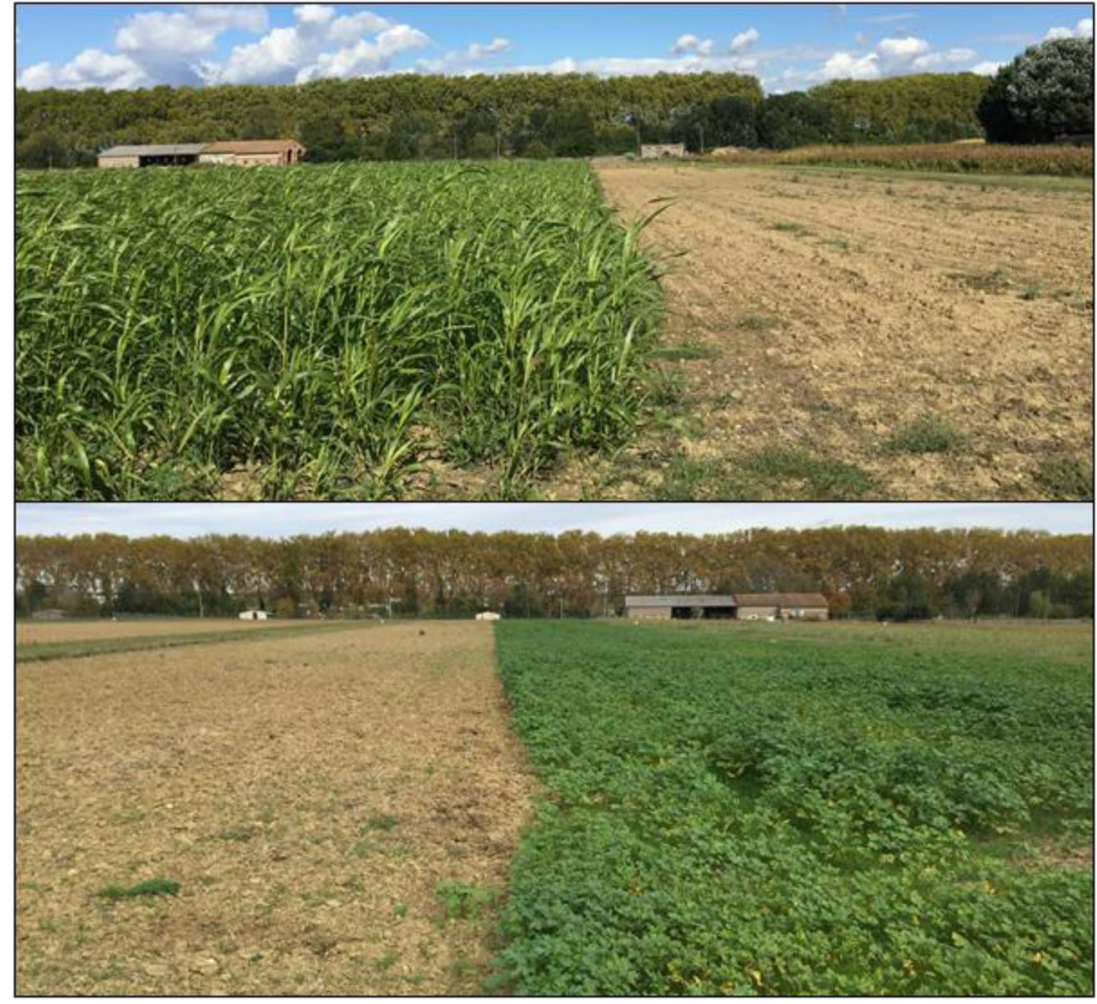

of effects depends greatly on the climate and soil context. Cover crop residues left as mulch after destruction can reduce evaporation, thus increasing soil water content (Alonso-Ayuso et al. 2014). The impact of cover crops on the factors influencing water balance makes it difficult to reach a consensus on their impact on water drainage. Several studies reported that cover crops reduce water drainage (Meisinger et al. 1991; Justes et al. 2012), while others reported no change (Qi et al. 2011b; Ward et al. 2012).

Several methods are available to measure water drainage, such as drained plots and lysimeters, but they are difficult to set up. Consequently, simulation modeling is frequently used (Gabriel et al. 2012; Constantin et al. 2015) to predict drainage in a variety of soil and climate contexts (Debaeke 2004).

Meta-analysis may better quantify the impact of cover crops on water drainage in a wide range of soil and climate contexts. This method is a quantitative systematic review that makes it possible to study global phenomenon over a wide range of experiments performed under a variety of circumstances (Glass 1976). In agronomy, it facilitates analysis of the variable effects of agricultural practices (Doré et al. 2011; Philibert et al. 2012). However, meta-analyses carried out in agronomy rarely perform sensitivity analysis or estimate publication bias. Philibert et al. (2012) highlighted that only $8 \%$ and $16 \%$ of them had done so, respectively. Since these analyses are needed to obtain a relevant and robust result, it is recommended to perform them both.
Meta-analysis has been used to examine impacts of cover crops on maize yields (Miguez and Bollero 2005), carbon sequestration (Poeplau and Don 2015), and nitrate leaching (Tonitto et al. 2006; Quemada et al. 2013; Valkama et al. 2015). However, meta-analysis of impacts of cover crops on water balance and drainage is lacking.

We used a meta-analysis approach to quantify the impact of cover crops on water drainage compared to that of fallow bare soil, i.e., without plant cover, under temperate climates, such as in Europe and North America.

\section{Materials and methods}

We followed five steps for a high-quality meta-analysis, as recommended and detailed in Philibert et al. (2012): (1) searching for papers in a scientific database, (2) extracting data from the papers' studies, (3) using weighting to calculate the mean effect size, (4) investigating publication bias, and (5) performing a sensitivity analysis.

\subsection{Database search}

We searched the Web of Science database (27 Sep 2017) for papers written in English using the following query:

"Topic $=(($ cover crop* OR green manure OR catch crop* $)$ AND (drain*) NOT vine* NOT orchard* NOT banana* NOT 
microbial* NOT rice NOT residu* NOT grape* NOT greenhouse NOT carbon NOT bacteri*))"

The search identified 436 papers. We then added 18 other papers from a review paper (Justes et al. 2012; Tribouillois et al. 2016) not found in our query but with all the query markers of our study. These papers were not specifically focused on drainage and therefore not found by our query. Based on the title and abstract, we excluded papers that did not study cover crops and water drainage or water balance, leaving 122 papers to be screened by reading the full text.

To be included in the meta-analysis, papers had to fulfill all of the following criteria:

(1) Contain data on water drainage, which we defined as water unavailable to plant roots and likely to recharge groundwater, i.e., measured at a depth of $90 \mathrm{~cm}$ or more

(2) Compare the impact of cover crops to that of fallow bare soil, without plant cover

(3) Cover crops sown in summer or autumn after the cash crop harvest and destroyed (soil tillage) or terminated (crushing or herbicide) before sowing the next cash crop

(4) Provide drained plot or lysimeter measurements or soilcrop model outputs

(5) Perform studies under climates of class B, C, or D of the Köppen-Geiger classification (Peel et al. 2007) in order to represent temperate climates

(6) Studies performed at the field scale

We read the 123 papers retained for their potential interest based on key words, and selected only 28 based on their relevance for analyzing our question. Moreover, since four of them compared field measurements to values simulated using soil-crop modeling for the same field and experiment, we divided each of them into two separate cases, resulting in 32 studies.

\subsection{Data extracted from studies}

We extracted the variables available and potential factors explaining the results, from each study, as follows:

(1) Method used to obtain drainage: (i) field measurements using lysimeters or drained plots or (ii) simulation model outputs

(2) Drainage (in $\mathrm{mm}$ ) under the cover crop $\left(X_{C C}\right)$ for each year or site depending on the study

(3) Drainage (in $\mathrm{mm}$ ) under bare soil $\left(X_{B S}\right)$ for each year or site depending on the study

(4) Geographic location and climate associated

(5) Soil textural class: silt, clay, sand, or loam (Ditzler et al. 2017)

(6) Cover crop biomass at destruction classified in two classes $(<$ and $>1.5 \mathrm{t} / \mathrm{ha})$
(7) Annual precipitation (in $\mathrm{mm}$ )

(8) Season of cover crop sowing: summer or autumn

All data were extracted from the papers' text, tables, and figures using the web application WebPlotDigitizer (Table 1).

\subsection{Data analysis}

\subsubsection{Calculating the mean difference in drainage}

In each study, for each year or site experiment, we calculated a difference in drainage $(D)$ between the cover crop treatment $\left(X_{C C}\right)$ and the bare soil treatment $\left(X_{B S}\right)$ :

$D=X_{C C}-X_{B S}$

We calculated individual effect size of each study $\left(D_{i}\right)$; it is the mean difference between water drainage under the cover crop and that under bare soil.

$D_{i}=\bar{D}$

The number of replication of the experiment $(n)$ is also extracted for the calculation of the standard deviation of the mean difference in drainage $\left(\sigma_{D_{i}}\right)$.

\subsubsection{Calculating standard deviations and confidence intervals}

For each study that included several experimental year or site, we calculated standard deviations associated with the difference in drainage.

$\sigma_{D_{i}}=\sqrt{\frac{\sum\left(D_{i}-\overline{D_{i}}\right)^{2}}{n}}$

We then used this standard deviation to calculate a $95 \%$ confidence interval.

$C I_{95 \%}=\left[D_{i}-1.96 \sigma_{D} ; D_{i}+1.96 \sigma_{D}\right]$

Following Hossard et al. (2016), to avoid underestimating the variability, we assigned the maximum standard deviation of our dataset to studies without any.

\subsubsection{Calculating mean effect size}

Heterogeneity of $D_{i}$ in the database was tested by computing the Q statistics (Hedges et al. 1999). We used a random-effects model to estimate the mean effect size $\left(\mu_{e s t}^{R E}\right)$. With this statistical model, we assumed that the true effect could vary among studies. We selected this approach because studies differed greatly in how they measured or simulated drainage, the duration of experiments/simulations, the precision/accuracy of 
Table 1 Characteristics of the papers selected for the meta-analysis, indicating the country in which they were performed, the method used (field measurements or simulation model), soil texture, seasons of cover crop (CC) sowing, rain level (a: $<750 \mathrm{~mm}$, b: $>750 \mathrm{~mm}$ ), and CC biomass (t/ha). USA United States, UK United Kingdom

\begin{tabular}{|c|c|c|c|c|c|c|}
\hline Paper & Country & Study method & Soil texture & CC sown & Rain level & $\mathrm{CC}$ biomass (t/ha) \\
\hline Volk and Bell (1945) & USA & Measurements & Loam & - & - & - \\
\hline Martinez and Guiraud (1990) & France & Measurements & Loam & Summer & a & 3.8 \\
\hline Meisinger et al. (1991) & USA & Model & - & Summer & - & - \\
\hline Davies et al. (1996) & UK & Measurements & Loam & Summer & $\mathrm{a}$ & 1.0 \\
\hline Milburn et al. (1997) & Canada & Measurements & Loam & Summer & $\mathrm{a}$ & - \\
\hline Justes et al. (1999) & France & Measurements & Calcareous & Summer & a & 1.4 \\
\hline Shepherd and Webb (1999) & UK & Measurements & Sand & Summer & a & 1.5 \\
\hline Logsdon et al. (2002) & USA & Measurements & Silt & - & $\mathrm{b}$ & - \\
\hline Strock et al. (2004) & USA & Measurements & Clay & Autumn & a & 1.4 \\
\hline \multirow[t]{2}{*}{ Feyereisen et al. (2006) } & USA & Measurements & Clay & Autumn & a & 1.4 \\
\hline & USA & Model & Clay & Autumn & a & 1.3 \\
\hline Kaspar et al. (2007) & USA & Measurements & Silt & Autumn & $\mathrm{b}$ & 1.7 \\
\hline Tonitto et al. (2007) & USA & Measurements & Clay & - & - & - \\
\hline Hooker et al. (2008) & Ireland & Measurements & Loam & - & a & - \\
\hline Li et al. (2008) & USA & Model & Silt & Autumn & $\mathrm{b}$ & 1.9 \\
\hline Constantin et al. (2010) & France & Measurements & - & Summer & - & - \\
\hline Qi and Helmers (2010) & USA & Measurements & Clay & Autumn & $\mathrm{b}$ & 2.7 \\
\hline Salmerón et al. (2010) & Spain & Measurements & Silt & Autumn & $\mathrm{b}$ & 5.2 \\
\hline Qi et al. 2011a & USA & Measurements & Clay & Autumn & $\mathrm{b}$ & 1.1 \\
\hline \multirow[t]{2}{*}{ Qi et al. (2011b) } & USA & Measurements & Clay & Autumn & $\mathrm{b}$ & 0.9 \\
\hline & USA & Model & Clay & Autumn & $\mathrm{b}$ & 1.0 \\
\hline Gabriel et al. (2012) & Spain & Model & Clay & Autumn & $\mathrm{a}$ & - \\
\hline Kaspar et al. (2012) & USA & Measurements & Silt & - & $\mathrm{b}$ & 1.0 \\
\hline Daigh et al. (2014) & USA & Measurements & Silt & Summer & $\mathrm{b}$ & - \\
\hline Malone et al. (2014) & USA & Model & Silt & Autumn & $\mathrm{b}$ & 2.2 \\
\hline Tosti et al. (2014) & Italy & Measurements & Clay & Summer & a & 6.9 \\
\hline Plaza-Bonilla et al. (2015) & France & Model & Clay & Summer & a & 1.8 \\
\hline \multirow[t]{2}{*}{ Martinez-Feria et al. (2016) } & USA & Measurements & Silt & Autumn & $\mathrm{b}$ & 1.0 \\
\hline & USA & Model & Silt & Autumn & $\mathrm{b}$ & 1.2 \\
\hline Tribouillois et al. (2016) & France & Model & - & Summer & - & - \\
\hline \multirow[t]{2}{*}{ Malone et al. (2017) } & USA & Measurements & Silt & Autumn & $\mathrm{b}$ & 1.7 \\
\hline & USA & Model & Silt & Autumn & $\mathrm{b}$ & 2.1 \\
\hline
\end{tabular}

measurements/predictions, the soil and climate context, and cover crop species. This method required considering two sources of variance: (i) within-study variance $\left(\sigma_{i}^{2}\right)$ and (ii) between-study variance $\left(\sigma_{b}^{2}\right)$ in the effect size, described by a probability distribution (Hedges et al. 1999). Studies were assigned weights $\left(w_{i}\right)$ to minimize both sources:

$w_{i}=\frac{1}{\sigma_{i}^{2}+\sigma_{b}^{2}}$

Finally, the weights of the studies analyzed (indicated as $P$ in the equation) were used to calculate mean effect size: $\mu_{e s t}^{R E}=\frac{\sum_{i=1}^{P} w_{i} D_{i}}{\sum_{i=1}^{P} w_{i}}$

We used the "metafor" package, "rma" function, and "REML" method (Viechtbauer 2010) of R software to perform the meta-analysis. Between-study variance was calculated using the maximum and restricted maximum likelihood methods. The standard deviation of mean effect size $\left(\sigma_{\mu}\right)$ equaled the reciprocal of the sum of the studies' weights. The $95 \%$ confidence interval of the mean effect size was then calculated. 
We conducted two separate meta-analysis to calculate the mean effect size: (i) one for field experiment studies and (ii) another for studies based on modeling.

\subsection{Mean effect size by study factor}

In the final step, we estimated the mean effect size (Eq. 6) of studies grouped by factors leading to four independent analyses: (i) soil texture, (ii) sowing seasons of cover crops and, to test the effect of cumulative transpiration on water drainage, (iii) biomass produced by cover crops (greater than or less than $1.5 \mathrm{t} / \mathrm{ha}$ ), and (iv) precipitation level (greater than or less than $800 \mathrm{~mm}$ ). We analyzed those factor effects only on field experiment studies since data with modeling were too few. Means were considered to be significantly different from one to another if their 95\% CIs were non-overlapping.

\subsection{Sensitivity analysis and publication bias}

\subsubsection{Sensitivity analysis}

We performed a sensitivity analysis to test the robustness of the random-effects model. We estimated three other mean effect sizes (and their 95\% confidence intervals) and then used the Akaike information criterion (AIC), which estimates the relative quality of model parametrization, to select the best statistical model. The model with the smallest AIC is considered best because it minimizes the risk of overparametrization and has the lowest calculation error.

We also evaluated the mean effect size using the mean standard deviation of other studies in the dataset (instead of the maximum) for studies that had not included a standard deviation or number of values. After calculating the between-study variance with the DerSimonian and Laird method, we compared the mean effect size estimated by a fixed-effect model to that of our previous random-effects model. A fixed-effect model is used when it is assumed that all studies share the same mean effect size. We estimated the mean effect size by removing one after the other ten studies with the biggest weight.

\subsubsection{Publication bias}

Publication bias can be an issue in meta-analysis since significant results are easier to publish than non-significant (Borenstein et al. 2009). We estimated publication bias by analyzing results graphically using a funnel plot, a common representation in meta-analysis (Light and Pillemer 1984). The funnel plot represents the inverse of the standard deviation of each study as a function of its individual effect size. It assumes that the more precise studies (at the top) will lie closer to the mean and that studies with less precision (at the bottom) will be spread around the mean effect size at the bottom. It should result in an inverted V-shape centered around the mean effect size.

\section{Results and discussion}

\subsection{Cover crops have variable effects on water drainage}

The difference in mean drainage under cover crops compared to that of bare soil varies greatly among the studies, varying from a maximum of $110 \mathrm{~mm}$ reduction to a $40 \mathrm{~mm}$ increase (Fig. 2). This variability on the effect is not unexpected since the studies cover a large range of soil, climate, and cover crop management and development. Since cover crops increase evapotranspiration (Nielsen et al. 2015b) and can also improve infiltration and reduce runoff (Yu et al. 2016), the range of effect is not surprising. Nevertheless, the vast majority of studies described a reduction in drainage, and more than 50\% of studies described a reduction in a narrow range of 10 $40 \mathrm{~mm}$. There is a larger variability in data issued of studies based on measurements than of those based on modeling. The lowest variability in modeling could be explained because all processes are not represented in models. For example, the reduction of runoff and the increase of infiltration due to cover crops is usually not taken into account. However, their means are quite close $(-30 \mathrm{~mm}$ and $-33 \mathrm{~mm}$, respectively, for studies based on modeling and studies based on measurements) which indicates a robust estimation of the cover crop effect on the reduction of drainage, whatever the method used for its evaluation (Fig. 2).

\subsection{Cover crops reduce drainage}

Cover crops reduce drainage compared to that of bare soil: the mean effect size of the meta-analysis was $-27 \mathrm{~mm}$ for studies based on measurements and $-32 \mathrm{~mm}$ for studies based on

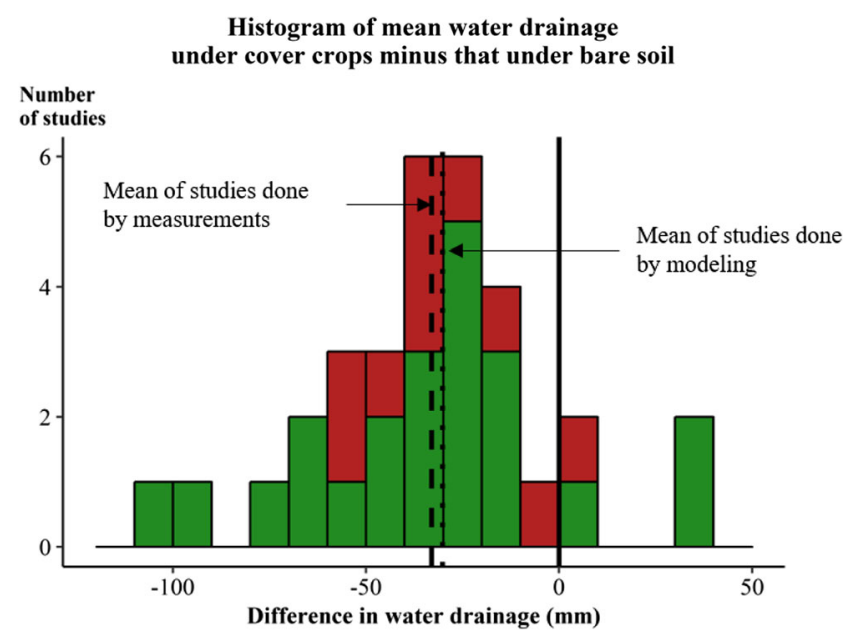

Fig. 2 Histogram of mean water drainage difference between cover crops and bare soil, grouped into $10 \mathrm{~mm}$ classes, among the 32 studies. In green, field measurement studies, and in red, modeling studies 
modeling. The $95 \%$ confidence interval of the effect size was very close: $20-34 \mathrm{~mm}$ for studies based on measurements and 21-43 mm for studies based on modeling (Fig. 3). It was larger for studies based on modeling because there is less studies to calculate the mean effect size (22 studies versus 10 studies).

This result is in agreement with the review of Justes et al. (2012) based on field measurements and simulation results using the STICS soil-crop model (Brisson et al. 2003). They reported that cover crops reduce water drainage by $20-50 \mathrm{~mm}$, which represents from less than 10 to $25 \%$ of annual drainage under cropping systems depending on the region of France. Water drainage under bare soil among the studies in our dataset varied greatly $(0-600 \mathrm{~mm})$ due to the influence of factors such as climate, irrigation, and soil hydraulic characteristics. As a result, the same reduction in millimeters could represent very different proportions on annual drainage and consequently impact on groundwater recharge. In rainy regions, $27 \mathrm{~mm}$ represents a small percentage of annual drainage. For example, in Iowa (USA), drainage could reach more than $500 \mathrm{~mm}$ in region where rainfall exceeds $800 \mathrm{~mm}$ per year (Logsdon et al. 2002; Kaspar et al. 2012). In contrast, in drier regions in temperate climate zones (e.g., southern France), such reduction in drainage could represent most or all of the annual drainage (Plaza-Bonilla et al. 2015). Simulation models tended to predict greater reduction in water drainage than that observed in field measurements (lysimeters and drained plots) (Li et al. 2008; Qi et al. 2011b; Malone et al. 2017). Crop soil models can overestimate cover crop biomass when certain limiting factors are not accurately represented (e.g., water and nutrient limitations) or not represented at all (e.g., pests and diseases).

\subsection{No significant effect of factors but some trends observed}

The meta-analysis clearly highlighted that cover crops reduce water drainage. Conversely, it did not indicate a significant trend for the effects of factors that could explain the variability in reduced drainage. Because so few studies were available, it was difficult to find statistically significant difference. Nonetheless, we observed a few trends in the mean effect size of groups within certain factor categories. Although never significant, those differences in mean effect size between groups within the factor categories were sometimes large and have a clear functional explanation.

The expected relationship between biomass and drainage is not observable on the two levels of biomass. The reduction in drainage is a little bit greater when cover crops had less than $1.5 \mathrm{t} / \mathrm{ha}$ of biomass but not significant. This result is surprising because one can think that a bigger cover crop biomass lead to a greater evapotranspiration through an increase of cover
Fig. 3 Mean effect size (circles) and $95 \% \mathrm{CI}$ (horizontal lines) of the difference in mean drainage for field measurement studies or modeling studies (at the top) and as a function of certain factors (only for studies done by measurements): (1) soil texture, (2) sowing season, (3) precipitation level, and (4) cover crop biomass. The letter " $n$ " is the number of observations for each group within a factor category
Difference in water drainage for all groups

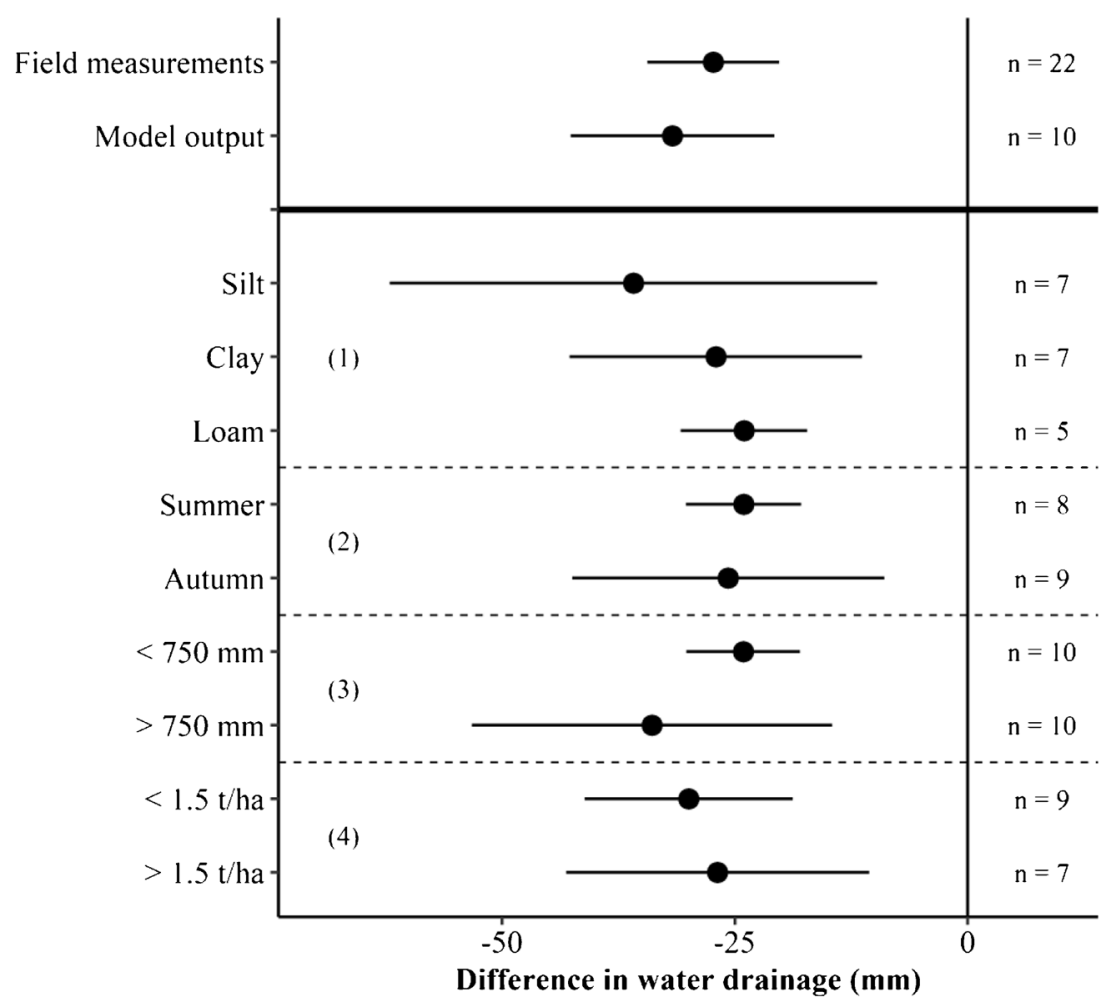


transpiration, despite the reduction of soil evaporation. A hypothesis may be that cover crops increase evapotranspiration up to a certain level of biomass, and after this threshold, the reduction of soil evaporation due to the cover becomes predominant. In addition, root biomass is often correlated with aerial biomass, a greater aerial biomass leading to a more develop rooting system. Several authors indicate that cover crop roots may structure the soil, increased water infiltration and soil water availability (Chen et al. 2014; Basche et al. 2016; Yu et al. 2016). The effect of cover crops with high aerial biomass on soil structure with an increase of soil water content may conduct to this result on water drainage compare to cover crops with lower biomass.

An observable trend is the influence of precipitation level on the reduction of water drainage. Indeed, there is a greater reduction in studies with more than $800 \mathrm{~mm}$ of precipitation per year than studies with low precipitation (around $10 \mathrm{~mm}$ ) (Fig. 3). In dry regions with low drainage, cover crops can cancel all drainage. If the drainage was more important, maybe the reduction would be so. However, the confidence interval $95 \%$ of the group with high precipitation is too wide that it is not possible to be conclusive regarding this factor. It also seems to have a larger reduction in water drainage in silt and clay soils than in loam soils. However, their confidence intervals are quite wide and this trend is hard to understand if it is not just random. The season of sowing cover crops did not influence reduction in water drainage. This result is also surprising because, in summer, cover crop development and low rainfall may reduce soil water content and thus water drainage later in autumn and winter. In contrast, autumn rainfall can compensate for the water used for cover crop transpiration when they are sown at this season.

The lake of impact of these different factors suggested that there are probably confounding effects since the database did not cover all the possible combinations between soil type, climate characteristics, cover crop species, period of sowing, and destruction. Indeed, the impact of cover crops on water drainage certainly results from the interaction of climate, soil, and cover crop management (i.e., density and date of sowing and destruction). However, the low numbers of references studying drainage do not allow to give a large-scale answer on the impact of cover crops on drainage compare to that of bare soil and particularly on the determining factors conditioning this effect.

\subsection{Qualitative analysis of the meta-analysis: the result obtained is robust}

The test of heterogeneity was significant and the AIC of the random-effect model was lower than other tested models, and then the homogeneity was not demonstrated. Varying the methods used to construct the random-effects model had little influence on the result. Mean effect size in the sensitivity analysis always indicates a reduction in water drainage, ranging from 32 to $26 \mathrm{~mm}$, concluding to a robust estimate. The result of our meta-analysis does not change when removing the data with the highest weigh from the database (Fig. 4a). This figure shows that when removing the four more weighed studies, the effect is approximately the same even if the standard deviation increase. Beyond that, the mean reduction of drainage tend to slightly increase until $-42 \mathrm{~mm}$ when 10 studies are removed. Obtaining the same effect when removing studies proves that the results on drainage reduction are not dependent on one or two dominant studies which strengthen its robustness.

The funnel plot assessing publication bias shows studies distributed symmetrically on both sides of the mean effect size (Fig. 4b). Studies with the lowest variability lay closest to the mean effect size (at the top of the graph). It is important to note that this observation is valid for data issued from studies based on measurements and on modeling.

The many tests of robustness and sensitivity analysis applied allow us to conclude that the effect of cover crops on drainage reduction obtain in this meta-analysis is robust. The reduction of approximately $30 \mathrm{~mm}$ of drainage is found throughout the different analysis, even if the main factors could not be identify.

\subsection{The lack of available references on the relationship between cover crop management and water balance}

Despite reducing annual water drainage, cover crops are known to decrease efficiently nitrate leaching, providing an ecosystem service of nitrate capture or catching (catch crop function) that decreases water pollution (Tonitto et al. 2006). Cover crops also provide multiple services, such as protecting soil from erosion, green manure effect, or carbon sequestration (Justes 2017). However, and in addition to drainage reduction impacting groundwater resources, cover crops may also reduce soil water content at sowing of the subsequent cash crop, which may decrease its emergence rate and early growth, particularly if they are destroyed close to its sowing date (Unger and Vigil 1998; Mitchell et al. 2015; Nielsen et al. 2015b). Irrigation can compensate for a lack of soil water but means higher costs for farmers and is not always available on farm. In addition, not all fields can be irrigated, and in certain regions in the world, more droughts and less water mean that irrigation is not a viable solution. If we were not able in this meta-analysis to point out the main factors driving the intensity of these negative effects on water dynamics, it would be useful to study relationships between cover crop management and soil water balance in various pedoclimatic conditions, such as the effects of (i) choice of species and cultivar, (ii) sowing date, (iii) destruction date, and (iv) method of destruction (tillage, frost, or herbicide) on biomass production and the associated evapotranspiration. It is highly likely that cover crop growth, cover crop duration, and water drainage interact. 


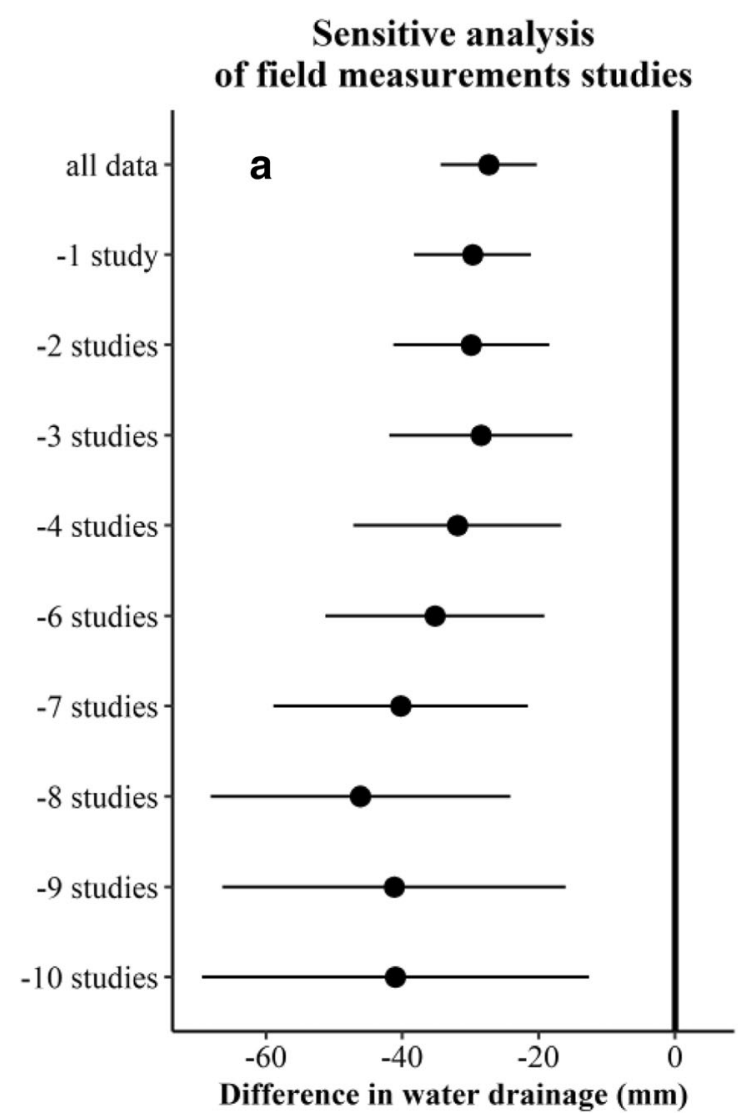

Fig. 4 a Sensitive analysis of data done by measurements. The $x$-axis represents the mean size effect of reduction in water drainage and $y$-axis shows the number of studies removed according their standard deviation, the study with the lowest standard deviation being removed. b Funnel plot

A better understanding of those relationships would allow to adapt cover crops' management to maximize positive effect (e.g., $\mathrm{N}$ and $\mathrm{C}$ balances) while limiting the negative ones on water, according to the pedoclimatic conditions.

If field experiments are useful to gather knowledge on those interactions, they are costly and time-consuming and may experience large variability in weather over time. Also, it may not be possible to extrapolate results from one soil and climate context to another due to strong dynamic interactions between cropping and pedoclimatic conditions. Simulation modeling is another approach to understanding soil $\times$ climate $x$ crop interactions and their impact on water balance (Meisinger et al. 1991; Basche et al. 2016). Modeling offers many opportunities to investigate selection and management of cover crops in cropping systems over several years with soil and climate variability (Qi et al. 2011b; Malone et al. 2014).

\subsection{An impact on groundwater recharge to assess at a larger scale}

To increase the use of cover crops to mitigate nitrate pollution in nitrate-sensitive areas, recycle nitrogen in the system, and provide other ecosystem services, cover crop management

\section{Funnel plot}

$1 /$ standard deviation of individual effect size

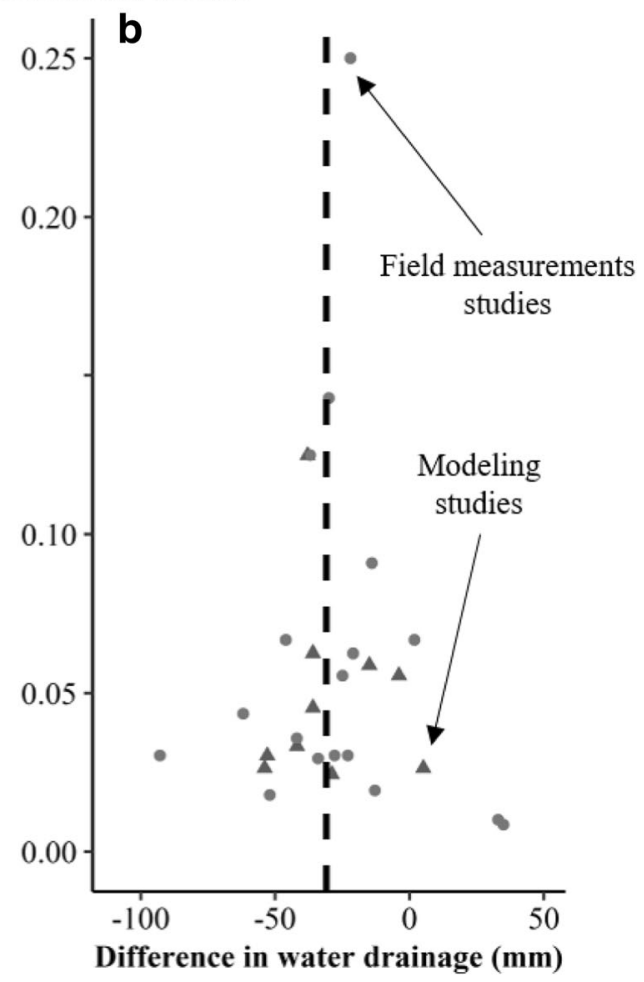

representing the inverse of the standard deviation as a function of the study's individual effect size. Only studies reporting standard deviations were considered (28 differences in drainage out of 32). The dashed line represents the mean effect size of the meta-analysis

must optimize the compromise between services and disservices for water groundwater recharge. The meta-analysis indicates a mean reduction in groundwater recharge of $270 \mathrm{~m}^{3} / \mathrm{ha}$ (i.e., $27 \mathrm{~mm}$ ), which represents most of the groundwater recharge in certain regions in dry years (Constantin et al. 2010; Plaza-Bonilla et al. 2015; Martinez-Feria et al. 2016). Then, a wider use of cover crops could pose a problem at the watershed scale if groundwater is shallow. According to the IPCC (2013), which predicts more droughts, extreme events, and a greater variability in rainfall in certain temperate regions, this reduction could become a crucial issue, as Tribouillois et al. (2018) have shown. Consequently, for shallow groundwater that is recharged mainly by drainage under soils of arable cropping systems, the reduction in drainage caused by cover crops could decrease groundwater reserves, which provide water for cities and irrigation, sustain the base flow of rivers, and support aquatic biodiversity. Studies at the field scale are not sufficient to assess the effect of cover crop on hydrology at a watershed scale. Since watersheds have agricultural as well as non-agricultural lands, such as forests or grasslands, in various proportion, it is hard to predict the impact on hydrology based on field-scale result. To do so, one would need to use agro-hydrological models to be able to quantify the impact 
of cover crops on water dynamics at this scale, such as the SWAT model or the MAELIA platform (Garg et al. 2012; Therond et al. 2014). It would also be useful to develop tools to find a compromise between cover crop-targeted services (e.g., nitrate capture, green manure effect) and disservices (impact on soil water availability for the subsequent cash crop and groundwater recharge).

\section{Conclusion}

The impact of cover crops on annual water drainage varies according to the soil and climate context. Our meta-analysis indicated a reduction in drainage in $90 \%$ of the studies analyzed and a mean weighted reduction between 32 and $27 \mathrm{~mm}$ compared to that of bare soil. The sensitivity analysis and assessment of publication bias indicated that the metaanalysis is robust and insensitive to individual studies. However, we were unable to determine the key factors that explained the variability in reduced drainage. This is mainly due to the low number of published studies usable for the analysis and also due to strong interactions between soil, climate, cover crop used, and cropping system in relation to the dynamics of processes. More field experiments with cover crops and water balance measurements and simulation studies using validated dynamic soil-crop models are then needed. This may help assessing the impacts of various factors such as soil, climate, cover crop biomass, and management, and their interactions on water balance and drainage.

Acknowledgments Thanks go to Michelle and Michael Corson for proofreading and correcting the English. The authors also thank François Brun and David Makowski for advice on performing the meta-analysis and Delphine Burger-Leenhardt for proofreading the manuscript.

Funding This study was funded by the Adour-Garonne water agency (BAGAGES project) and the Occitanie region (CLE BAGAGES-Cisol project).

\section{Compliance with ethical standards}

Conflict of interest The authors declare that they have no conflict of interest.

\section{References}

Alonso-Ayuso M, Gabriel JL, Quemada M (2014) The kill date as a management tool for cover cropping success. PLoS One 9: e109587. https://doi.org/10.1371/journal.pone.0109587

Basche AD, Archontoulis SV, Kaspar TC, Jaynes DB, Parkin TB, Miguez FE (2016) Simulating long-term impacts of cover crops and climate change on crop production and environmental outcomes in the Midwestern United States. Agric Ecosyst Environ 218:95-106. https://doi.org/10.1016/j.agee.2015.11.011
Borenstein M, Hedges LV, Higgins JPT, Rothstein HR (2009) Introduction to meta-analysis. Psychother Res J Soc Psychother Res 19:421. https://doi.org/10.1002/9780470743386

Brisson N, Gary C, Justes E, Roche R, Mary B, Ripoche D, Zimmer D, Sierra J, Bertuzzi P, Burger P, Bussière F, Cabidoche YM, Cellier P, Debaeke P, Gaudillère JP, Hénault C, Maraux F, Seguin B, Sinoquet H (2003) An overview of the crop model STICS. Eur J Agron 18: 309-332. https://doi.org/10.1016/S1161-0301(02)00110-7

Chen G, Weil RR, Hill RL (2014) Effects of compaction and cover crops on soil least limiting water range and air permeability. Soil Tillage Res 136:61-69. https://doi.org/10.1016/j.still.2013.09.004

Constantin J, Mary B, Laurent F, Aubrion G, Fontaine A, Kerveillant P, Beaudoin N (2010) Effects of catch crops, no till and reduced nitrogen fertilization on nitrogen leaching and balance in three long-term experiments. Agric Ecosyst Environ 135:268-278. https://doi.org/ 10.1016/j.agee.2009.10.005

Constantin J, Le Bas C, Justes E (2015) Large-scale assessment of optimal emergence and destruction dates for cover crops to reduce nitrate leaching in temperate conditions using the STICS soil-crop model. Eur J Agron 69:75-87. https://doi.org/10.1016/j.eja.2015. 06.002

Debaeke P (2004) Scenario analysis for cereal management in waterlimited conditions by the means of a crop simulation model (STICS). Agronomie 24:315-326. https://doi.org/10.1051/agro

Demenois J (2017) Mobiliser l'expertise scientifique au niveau international : l'exemple de l'initative "4 pour 1000 : Les sols pour la sécurité alimentaire et le climat ". pp 4-5

Ditzler C, Scheffe K, Monger HC (2017) Soil science division staff. Soil survey manual, USDA, Washington, D.C

Doré T, Makowski D, Malézieux E et al (2011) Facing up to the paradigm of ecological intensification in agronomy: revisiting methods, concepts and knowledge. Eur J Agron 34:197-210. https://doi.org/10. 1016/j.eja.2011.02.006

Eshel G, Egozi R, Goldwasser Y, Kashti Y, Fine P, Hayut E, Kazukro H, Rubin B, Dar Z, Keisar O, DiSegni DM (2015) Benefits of growing potatoes under cover crops in a Mediterranean climate. Agric Ecosyst Environ 211:1-9. https://doi.org/10.1016/j.agee.2015.05. 002

Gabriel JL, Muñoz-Carpena R, Quemada M (2012) The role of cover crops in irrigated systems: water balance, nitrate leaching and soil mineral nitrogen accumulation. Agric Ecosyst Environ 155:50-61. https://doi.org/10.1016/j.agee.2012.03.021

Garg KK, Bharati L, Gaur A, George B, Acharya S, Jella K, Narasimhan B (2012) Spatial mapping of agricultural water productivity using the SWAT model in Upper Bhima Catchment, India. Irrig Drain 61: 60-79. https://doi.org/10.1002/ird.618

Glass GV (1976) Primary, secondary, and meta-analysis of research. Am Educ Res Assoc 5:3-8. https://doi.org/10.3102/0013189X005010003

Haramoto ER, Gallandt ER (2005) Brassica cover cropping: I. Effects on weed and crop establishment. Weed Sci 53:695-701. https://doi.org/ 10.1614/WS-04-162R.1

Hedges LV, Gurevitch J, Curtis PS (1999) The meta-analysis of response ratios in experimental ecology. Ecology 80:1150-1156

Hossard L, Archer DW, Bertrand M, Colnenne-David C, Debaeke P, Ernfors M, Jeuffroy MH, Munier-Jolain N, Nilsson C, Sanford GR, Snapp SS, Jensen ES, Makowski D (2016) A meta-analysis of maize and wheat yields in low-input vs. conventional and organic systems. Agron J 108:1155-1167. https://doi.org/10.2134/ agronj2015.0512

IPCC (2013) Climate change 2013: the physical science basis. Contribution of Working Group I to the Fifth Assessment Report of the Intergovernmental Panel on Climate Change. Intergov Panel Clim Chang Work Gr I Contrib to IPCC Fifth Assess Rep (AR5) (Cambridge Univ Press New York) 1535. https://doi.org/10.1029/ 2000JD000115 
Justes E (Editor) (2017) Cover crops for sustainable farming. $91 \mathrm{p}$. Editions Quae (France) and Springer (The Netherlands). https:// doi.org/10.1007/978-94-024-0986-4

Justes E, Beaudoin N, Bertuzzi P, Charles R, Constantin J, Dürr C, Hermon C, Joannon A, Le Bas C, Mary B, Mignolet C, Montfort F, Ruiz L, Sarthou JP, Souchère V, Tournebize J, IRO S (2012) Réduire les fuites de nitrate au moyen de cultures intermédiaires : conséquences sur les bilans d'eau et d'azote, autres services écosystémiques. Synthèse du rapport d'étude. INRA, France

Kaspar TC, Jaynes DB, Parkin TB, Moorman TB, Singer JW (2012) Effectiveness of oat and rye cover crops in reducing nitrate losses in drainage water. Agric Water Manag 110:25-33. https://doi.org/ 10.1016/j.agwat.2012.03.010

Li L, Malone RW, Ma L et al (2008) Winter cover crop effects on nitrate leaching in subsurface drainage as simulated by RZWQM-DSSAT. Trans ASABE 51:1575-1583. https://doi.org/10.13031/2013.25314

Light R, Pillemer D (1984) Summing up: the science of reviewing research

Logsdon SD, Kaspar TC, Meek DW, Prueger JH (2002) Nitrate leaching as influenced by cover crops in large soils monoliths. Agron J 94: 807-814

Malone RW, Jaynes DB, Kaspar TC, Thorp KR, Kladivko E, Ma L, James DE, Singer J, Morin XK, Searchinger T (2014) Cover crops in the upper midwestern United States: simulated effect on nitrate leaching with artificial drainage. J Soil Water Conserv 69:292-305. https://doi.org/10.2489/jswc.69.4.292

Malone RW, Kersebaum KC, Kaspar TC, Ma L, Jaynes DB, Gillette K (2017) Winter rye as a cover crop reduces nitrate loss to subsurface drainage as simulated by HERMES. Agric Water Manag 184:156169. https://doi.org/10.1016/j.agwat.2017.01.016

Martinez-Feria RA, Dietzel R, Liebman M, Helmers MJ, Archontoulis SV (2016) Rye cover crop effects on maize: a system-level analysis. Field Crop Res 196:145-159. https://doi.org/10.1016/j.fcr.2016.06.016

Meisinger JJ, Hargrove WL, Mikkelsen RL et al (1991) Effects of cover crops on groundwater quality. In: Cover crops for clean water. Soil and Water Conservation Society. pp 57-68

Miguez FE, Bollero GA (2005) Review of corn yield response under winter cover cropping systems using meta-analytic methods. Crop Sci 45:2318-2329. https://doi.org/10.2135/cropsci2005.0014

Mitchell JP, Shrestha A, Irmak S (2015) Trade-offs between winter cover crop production and soil water depletion in the San Joaquin Valley, California. J Soil Water Conserv 70:430-440. https://doi.org/10. 2489/jswc.70.6.430

Nielsen DC, Lyon DJ, Hergert GW, Higgins RK, Holman JD (2015a) Cover crop biomass production and water use in the Central Great Plains. Agron J 107:2047-2058. https://doi.org/10.2134/agronj15. 0186

Nielsen DC, Lyon DJ, Hergert GW, Higgins RK, Calderón FJ, Vigil MF (2015b) Cover crop mixtures do not use water differently than single-species plantings. Agron J 107:1025-1038. https://doi.org/ 10.2134/agronj14.0504

Peel MC, Finlayson BL, McMahon TA (2007) Updated world map of the Koppen-Geiger climate classification updated world map of the K * oppen-Geiger climate classification. Hydrol Earth Syst Sci 11:16331644. https://doi.org/10.5194/hess-11-1633-2007

Philibert A, Loyce C, Makowski D (2012) Assessment of the quality of meta-analysis in agronomy. Agric Ecosyst Environ 148:72-82. https://doi.org/10.1016/j.agee.2011.12.003

Plaza-Bonilla D, Nolot JM, Raffaillac D, Justes E (2015) Cover crops mitigate nitrate leaching in cropping systems including grain legumes: field evidence and model simulations. Agric Ecosyst Environ 212:1-12. https://doi.org/10.1016/j.agee.2015.06.014

Poeplau C, Don A (2015) Carbon sequestration in agricultural soils via cultivation of cover crops - a meta-analysis. Agric Ecosyst Environ 200:33-41. https://doi.org/10.1016/j.agee.2014.10.024
Qi Z, Helmers MJ, Kaleita AL (2011a) Soil water dynamics under various agricultural land covers on a subsurface drained field in northcentral Iowa, USA. Agric Water Manag 98:665-674. https://doi. org/10.1016/j.agwat.2010.11.004

Qi Z, Helmers MJ, Malone RW, Thorp KR (2011b) Simulating long-term impacts of winter rye cover crop on hydrologic cycling and nitrogen dynamics for a corn-soybean crop system. Trans ASABE 54:15751588

Quemada M, Baranski M, Nobel-de Lange MNJ, Vallejo A, Cooper JM (2013) Meta-analysis of strategies to control nitrate leaching in irrigated agricultural systems and their effects on crop yield. Agric Ecosyst Environ 174:1-10. https://doi.org/10.1016/j.agee.2013.04.018

Ryder MH, Fares A (2008) Evaluating cover crops (sudex, sunn hemp, oats) for use as vegetative filters to control sediment and nutrient loading from agricultural runoff in a Hawaiian watershed. J Am Water Resour Assoc 44:640-653. https://doi.org/10.1111/j.17521688.2008.00189.x

Schipanski ME, Barbercheck M, Douglas MR, Finney DM, Haider K, Kaye JP, Kemanian AR, Mortensen DA, Ryan MR, Tooker J, White C (2014) A framework for evaluating ecosystem services provided by cover crops in agroecosystems. Agric Syst 125:12-22. https:// doi.org/10.1016/j.agsy.2013.11.004

Therond O, Sibertin-blanc C, Lardy R et al (2014) Integrated modelling of social-ecological system : the MAELIA highresolution multi-agent platform to deal with water scarcity problems. 7th Intl Congr Env Model Software, San Diego, CA, USA 2014:8

Tonitto C, David MB, Drinkwater LE (2006) Replacing bare fallows with cover crops in fertilizer-intensive cropping systems: a meta-analysis of crop yield and N dynamics. Agric Ecosyst Environ 112:58-72. https://doi.org/10.1016/j.agee.2005.07.003

Tosti G, Benincasa P, Farneselli M, Tei F, Guiducci M (2014) Barleyhairy vetch mixture as cover crop for green manuring and the mitigation of N leaching risk. Eur J Agron 54:34-39. https://doi.org/10. 1016/j.eja.2013.11.012

Tribouillois H, Cruz P, Cohan JP, Justes E (2015) Modelling agroecosystem nitrogen functions provided by cover crop species in bispecific mixtures using functional traits and environmental factors. Agric Ecosyst Environ 207:218-228. https://doi.org/10.1016/j. agee.2015.04.016

Tribouillois H, Cohan JP, Justes E (2016) Cover crop mixtures including legume produce ecosystem services of nitrate capture and green manuring: assessment combining experimentation and modelling. Plant Soil 401:347-364. https://doi.org/10.1007/s11104-015-2734-8

Tribouillois H, Constantin J, Justes E (2018) Cover crops mitigate greenhouse gases balance but reduce drainage under climate change scenarios in temperate climate with dry summers. Glob Chang Biol 24: 1-17. https://doi.org/10.1111/gcb.14091

Unger PW, Vigil MF (1998) Cover crop effects on soil water relationships. J Soil Water Conserv 53:200-207

Valkama E, Lemola R, Känkänen H, Turtola E (2015) Meta-analysis of the effects of undersown catch crops on nitrogen leaching loss and grain yields in the Nordic countries. Agric Ecosyst Environ 203:93101. https://doi.org/10.1016/j.agee.2015.01.023

Viechtbauer W (2010) Conducting meta-analyses in R with the metafor package. J Stat Softw 36:1-48. https://doi.org/10.1103/PhysRevB. 91.121108

Ward PR, Flower KC, Cordingley N, Weeks C, Micin SF (2012) Soil water balance with cover crops and conservation agriculture in a Mediterranean climate. Field Crop Res 132:33-39. https://doi.org/ 10.1016/j.fcr.2011.10.017

Yu Y, Loiskandl W, Kaul HP, Himmelbauer M, Wei W, Chen L, Bodner G (2016) Estimation of runoff mitigation by morphologically different cover crop root systems. J Hydrol 538:667-676. https://doi.org/10. 1016/j.jhydrol.2016.04.060 
References of the meta-analysis

Constantin J, Mary B, Laurent F, Aubrion G, Fontaine A, Kerveillant P, Beaudoin N (2010) Effects of catch crops, no till and reduced nitrogen fertilization on nitrogen leaching and balance in three long-term experiments. Agric Ecosyst Environ 135(4):268-278. https://doi. org/10.1016/j.agee.2009.10.005

Daigh AL, Helmers MJ, Kladivko E, Zhou X, Goeken R, Cavdini J, Barker D, Sawyer J (2014) Soil water during the drought of 2012 as affected by rye cover crops in fields in Iowa and Indiana. J Soil Water Conserv 69(6):564-573. https://doi.org/10.2489/jswc.69.6. 564

Davies DB, Garwoodf TWD, Rochford ADH (1996) Factors affecting nitrate leaching from a calcareous loam in East Anglia. J Agric Sci 126(1):75-86. https://doi.org/10.1017/S0021859600088821

Feyereisen GW, Wilson BN, Sands GR, Strock JS, Porter PM (2006) Potential for a rye cover crop to reduce nitrate loss in southwestern Minnesota. Agron J 98(6):1416-1426. https://doi.org/10.2134/ agronj2005.0134

Gabriel JL, Muñoz-Carpena R, Quemada M (2012) The role of cover crops in irrigated systems: water balance, nitrate leaching and soil mineral nitrogen accumulation. Agric Ecosyst Environ 155:50-61. https://doi.org/10.1016/j.agee.2012.03.021

Hooker KV, Coxon CE, Hackett R, Kirwan LE, O'Keeffe E, Richards KGG (2008) Evaluation of cover crop and reduced cultivation for reducing nitrate leaching in Ireland. J Environ Qual 37(1):138-145. https://doi.org/10.2134/jeq2006.0547

Justes E, Mary B, Nicolardot B (1999) Comparing the effectiveness of radish cover crop, oilseed rape volunteers and oilseed rape residues incorporation for reducing nitrate leaching. Nutr Cycl Agroecosyst 55(3):207-220. https://doi.org/10.1023/A:1009870401779

Kaspar TCC, Jaynes DBB, Parkin TBB, Moorman TBB (2007) Rye cover crop and gamagrass strip effects on $\mathrm{NO}$ concentration and load in tile drainage. J Environ Qual 36(5):1503. https://doi.org/10. 2134/jeq2006.0468

Kaspar TC, Jaynes DB, Parkin TB, Moorman TB, Singer JW (2012) Effectiveness of oat and rye cover crops in reducing nitrate losses in drainage water. Agric Water Manag 110(3):25-33. https://doi.org/ 10.1016/j.agwat.2012.03.010

Li L, Malone RW, Ma L, Kaspar TC, Jaynes DB, Saseendran SA et al (2008) Winter cover crop effects on nitrate leaching in subsurface drainage as simulated by RZWQM-DSSAT. Trans ASABE 51(5): 1575-1583. https://doi.org/10.13031/2013.25314

Logsdon SD, Kaspar TC, Meek DW, Prueger JH (2002) Nitrate leaching as influenced by cover crops in large soils monoliths. Agron J 94(4): 807-814

Malone RW, Jaynes DB, Kaspar TC, Thorp KR, Kladivko E, Ma L, James DE, Singer J, Morin XK, Searchinger T (2014) Cover crops in the upper midwestern United States: simulated effect on nitrate leaching with artificial drainage. J Soil Water Conserv 69(4):292305. https://doi.org/10.2489/jswc.69.4.292

Malone RW, Kersebaum KC, Kaspar TC, Ma L, Jaynes DB, Gillette K (2017) Winter rye as a cover crop reduces nitrate loss to subsurface drainage as simulated by HERMES. Agric Water Manag 184:156169. https://doi.org/10.1016/j.agwat.2017.01.016

Martinez J, Guiraud G (1990) Alysimeter study of the effects of a ryegrass catch crop, during a winter wheat/maize rotation, on nitrate leaching and on the following crop. J Soil Sci 41(1):5-16. https://doi.org/10. 1111/j.1365-2389.1990.tb00040.x

Martinez-Feria RA, Dietzel R, Liebman M, Helmers MJ, Archontoulis SV (2016) Rye cover crop effects on maize: a system-level analysis. Field Crop Res 196:145-159. https://doi.org/10.1016/j.fcr.2016.06. 016

Meisinger JJ, Hargrove WL, Mikkelsen RL, Williams JR, Benson VW (1991). Effects of cover crops on groundwater quality. In: Cover crops for clean water. Soil and Water Conservation Society, pp $57-68$

Milburn P, MacLeod JA, Sanderson B (1997) Control of fall nitrate leaching from harvested potatoes on Prince Edward Island. Can Agric Eng 39(2):263-271

Plaza-Bonilla D, Nolot JM, Raffaillac D, Justes E (2015) Cover crops mitigate nitrate leaching in cropping systems including grain legumes: field evidence and model simulations. Agric Ecosyst Environ 212:1-12. https://doi.org/10.1016/j.agee.2015.06.014

Qi Z, Helmers MJ (2010) Soil water dynamics under winter rye cover crop in central Iowa. Vadose Zone J 9(1):53-60. https://doi.org/10. 2136/vzj2008.0163

Qi Z, Helmers MJ, Kaleita AL (2011) Soil water dynamics under various agricultural land covers on a subsurface drained field in northcentral Iowa, USA. Agric Water Manag 98(4):665-674. https:// doi.org/10.1016/j.agwat.2010.11.004

Qi Z, Helmers MJ, Malone RW, Thorp KR (2011) Simulating long-term impacts of winter rye cover crop on hydrologic cycling and nitrogen dynamics for a corn-soybean crop system. Trans ASABE 54(5): 1575-1588 Retrieved from http://lib.dr.iastate.edu/abe_eng_pubs

Salmerón M, Cavero J, Quílez D, Isla R (2010) Winter cover crops affect monoculture maize yield and nitrogen leaching under irrigated Mediterranean conditions. Agron J 102(6):1700-1709. https://doi. org/10.2134/agronj2010.0180

Shepherd MA, Webb J (1999) Effects of overwinter cover on nitrate loss and drainage from a sandy soil: consequences for water management? Soil Use Manag 15:1-116. https://doi.org/10.1111/j.14752743.1999.tb00073.x

Strock JS, Porter PM, Russelle MP, Strock SJ, Porter PM, Russelle MP (2004) Cover cropping to reduce nitrate loss through subsurface drainage in the northern U.S. corn belt. J Environ Qual 33(3): 1010. https://doi.org/10.2134/jeq2004.1010

Tonitto C, David MB, Drinkwater LE, Li C (2007) Application of the DNDC model to tile-drained Illinois agroecosystems: model calibration, validation, and uncertainty analysis. Nutr Cycl Agroecosyst 78(1):51-63. https://doi.org/10.1007/s10705-006-9076-0

Tosti G, Benincasa P, Farneselli M, Tei F, Guiducci M (2014) Barleyhairy vetch mixture as cover crop for green manuring and the mitigation of N leaching risk. Eur J Agron 54:34-39. https://doi.org/10. 1016/j.eja.2013.11.012

Tribouillois H, Cohan JP, Justes E (2016) Cover crop mixtures including legume produce ecosystem services of nitrate capture and green manuring: assessment combining experimentation and modelling. Plant Soil 401(1-2):347-364. https://doi.org/10.1007/s11104-0152734-8

Volk GM, Bell CE (1945) Some major factors in the leaching of calcium, potassium, sulfur and nitrogen from sandy soils. University of Florida Agricultural Experiment Station. Retrieved from http:// agris.fao.org/agrissearch/search.do?recordID=US201300455046 